and have better claims to be placed in the hands of modern students than those of $155^{\circ}$. But this is a question by itself; what I wished to insist upon was, that the Clarendon Press in its text-editions ought no longer to circulate the Textus Receptus.

3. Finally, Professor Sanday made a little mistake in writing : 'Cambridge prints the Stephanus text of 1550 with the Revisers' readings as variants'. It is not the Stephanus text of 1550 , but Beza's fifth and last text of 1598 (as being more likely than any other to be in the hands of King James's revisers). Whether the Cambridge Press, in like manner as the Clarendon does with Lloyd and Mill, 'still issues the text of Stephanus' is unknown to me ${ }^{1}$. Scrivener's reprints of Stephanus are, as far as I am aware, private undertakings, and his edition of Beza with the reading, of the Revisers, published for the University Press, ranks with Palmer, not with 'Lloyd ' or 'Mill'.

Eb. Nestre.

\title{
NOTES ON THE BISHOPS OF ST ANDREWS.
}

\section{Addenda et Corrigenda.}

DuRING the great schism, while Scotland up to I4I 7 adhered to the Anti-Popes, the Popes continued to make appointments to Scottish sees, which appointments in Scotland were wholly unrecognized and ineffective. The following may be recorded. (I) As already noticed (see p. 122 note) Alexander de Neville, archbishop of York (deposed I $3^{88}$ ), was translated by Urban VI to the bishopric of St Andrews in Scotland (Walsingham, Rolls Series, ii 179). The date of the bull is given as April 30, I388. He is the 'Alexander bishop of St Andrews' of subsequent letters of Urban VI and Boniface IX (C.P.R. iv $27 \mathrm{I}$, 326,343 ). He died in poverty at Louvain in May, 1392. (2) Thomas de Arundel (successor of Neville at York, translated to Canterbury in $\times 396$ ), while in banishment after his attainder, was translated to St Andrews by Boniface IX, Jan. 2 I, 1398. He was restored to Can. terbury in Oct. 1399 (see Hardy's Le Neve's Fasti). (3) John Trevor,

1 The Cambridge University Press publishes Beza's text of 1598, with the variants adopted by the Revisers at the foot of the page, as stated by Dr. Nestle. For this edition there is a good demand. It also still prints and publishes the Stephanus text of $155^{\circ}$, with the English of the Authorized Version in parallel columns (first edited by Scholefield in $183^{6}$-some small changes, e.g. of orthography, in later editions), as there is still some demand for this edition. Scrivener's reprint of the Stephanus text of $155^{\circ}$, with the variants of later editors and the Revisers at the foot of the page, is published by Messrs Deighton \& Bell, though printed at the Cambridge Press.-[EDD.] 
who had been provided bishop of St Asaph (Oct. 21, 1394-C. P. R. iv 48I), was translated to St Andrews in 1408 (see Eubel's Hierarchia Catholica i 88 note 5). Trevor died April 10, 1410 (Stubbs's Reg. Sanct. Angl. 2nd edit. 82).

Scheves (p. 256). His provision as coadiutor cum iure successionis was as early as Sep. 13, 1476 (Eubel ii 99).

Corrigendum (p. 259 note) : for 1572 read 1512.

Corrigendum (p. 260 note I). Delete the reference to the Black Book of Taymouth, which, however, may mark that Gavin Douglas's obit was observed on that day. His death must have occurred between Sep. 10, 1522, when his will was executed, and Sept. 19, 1522, when probate was granted. The will is printed in the introduction to Small's edition of the Poetical Works of Gavin Douglas i pp. cxvii ff. I owe this reference to the Rev. John Anderson of H. M. General Register House, Edinburgh.

J. DOWDEN. 